\title{
Determinants of China's OFDI Location Choices: A Comparison Study Between BRI Countries and Non-BRI Countries
}

\author{
Lili PAN \\ School of Economics and Management, University of Chinese Academy of Sciences, Beijing 100190, \\ China \\ E-mail: pll3068@163.com \\ Qianqian FENG \\ Institutes of Science and Development, Chinese Academy of Sciences, Beijing 100190, China; School \\ of Public Policy and Management, University of Chinese Academy of Sciences, Beijing 100049, China \\ E-mail: fengqianqian18@mails.ucas.ac.cn \\ Jianping LI \\ School of Economics and Management, University of Chinese Academy of Sciences, Beijing 100190, \\ China \\ E-mail:ljp@casipm.ac.cn

\section{Lin WANG*} \\ Glorious Sun School of Business and Management, Donghua University, Shanghai 201620, China \\ E-mail: wanglin@dhu.edu.cn

\begin{abstract}
In recent years, China's outward foreign direct investment (OFDI) has risen significantly, arousing considerable interest in the motivations and drivers of Chinese overseas investment. This paper selected 27 host country-related indicators and extracted the common factors using the factor analysis method. This paper discusses the determinants of China's OFDI location choice by using panel data regression method, and focuses on the differences between Belt and Road countries and nonBelt and Road countries. The results show that the favorable institutional environment and strong market demand of host countries have a positive influence on Chinese foreign investment. Besides, China's investment in Belt and Road Initiative countries is more prone to a country with less developed technology and unreasonable energy utilization. China's OFDI can promote technological progress in these countries and making full use of their advantage resources for economic development. As China's economy has entered a "new normal", its global influence has risen, and the relationship between the host countries and China has also mattered more on China's OFDI decisions. This effort provides important supports for optimizing the location choices of Chinese enterprises' foreign investment.
\end{abstract}

Keywords China's OFDI; location choice; the Belt and Road Initiative; panel data regression method

Received July 1, 2021, accepted November 25, 2021

Supported by the Social and Science Fund of Xinjiang (17BKS008) and General Project of Inner-Party Law Research Center (XJDG2019D02)

*Corresponding author 


\section{Introduction}

Outward foreign direct investment (OFDI) is a critical component of Chinese open economy and an important means of integrating Chinese economy into the global economy ${ }^{[1]}$. China's OFDI has risen significantly since 2000 and researched $\$ 136.91$ billion in 2019 . China has become the second-largest investor in the world. However, Chinese companies are still faced with a complex international situation when going global, and many uncertainties such as political, economic, financial and social risks in host countries are also important threatens ${ }^{[2]}$. To well-implement the foreign investment strategy of Chinese enterprises, an effective location choice is essential ${ }^{[3]}$.

In recent years, China's economic development has entered a "new normal", with slower economic growth, improved and upgraded economic structure, and a shift from the factor-driven and investment-driven economic growth to an innovation-driven one. China's macroeconomic development is faced with major tasks of reducing overcapacity, destocking, deleveraging, reducing costs and strengthening weak links. Under this background, the Chinese government is actively building a new system of the open economy, innovating ways of outbound investment, and deepening international cooperation on production capacity. The proposal of the Belt and Road Initiative (BRI) has provided a precious historical opportunity for Chinese enterprises to conduct international investment and cooperation. By the end of 2019, China's investment to BRI countries has risen up to $\$ 18.69$ billion, accounting for $13.7 \%$ of China's outward flows in the sample period. Considering the benefits of BRI, the determinants and effects of China's OFDI driven by BRI deserve serious attention ${ }^{[4]}$.

Exploring the influencing factors of China's OFDI location choice has become an important research topic in China's foreign economy and trade ${ }^{[5]}$. With the rapid growth of global transnational investment, international academic studies have carried out long-term and in-depth studies on foreign investment. The motivation and influencing factors of outbound investment of multinational enterprises have been effectively identified and analyzed ${ }^{[6,7]}$. However, these studies mostly focus on developed countries, which have limitations in guiding Chinese enterprises' overseas investment ${ }^{[2]}$. For a long time, there lacks reasonable strategic plans for choosing locations of enterprises' foreign investment. Therefore, it is necessary to systematically analyze the historical practice of China's OFDI and provide suggestions for optimizing the location choice of Chinese enterprises' overseas investment.

To scientifically analyze the influencing factors of China's OFDI, this paper selected 27 relevant factors based on the theoretical analysis and conclusions of research papers. Due to the correlation between some indictors, this paper extracted five common factors by the factor analysis method and further explored the influences of common factors on China's OFDI by panel data regression. Taking the sample countries of BRI countries and non-BRI countries, this paper found the difference in location choices. Besides, this paper also explored the heterogeneous effects of factors on China's OFDI in time and scale. This study can not only guide selecting the location of China's OFDI, but also improve the effectiveness of Chinese enterprises on OFDI.

This paper contributes to the literature in the following three aspects. First, based on the review on the theoretical and empirical literature, this paper establishes a comprehensive 
index list to analyze the influencing factors of China's OFDI. Second, given that the BRI has encouraged Chinese companies to invest abroad, this paper compares the determinants of China's OFDI for BRI countries and non-BRI countries. Third, this paper further analyzes the heterogeneity of the determinants of China's OFDI in terms of time and scale.

The remainder of the paper is organized as follows. Section 2 carries out a systematic review of existing research literature on foreign direct investment. Section 3 introduces the variable selection and data collection. The study design is displayed in Section 4. Section 5 displays empirical results and analysis. Section 6 concludes and provides policy suggestions.

\section{Literature Review}

Foreign direct investment (FDI) refers to an investment from a company or entity established in one country to another country ${ }^{[8]}$. FDI is generally considered the most stable foreign investment, which plays an important role in promoting the economic development of both the home country and the host country ${ }^{[9]}$. On the one hand, FDI creates employment opportunities, technology spillover and improves output efficiency in host countries ${ }^{[10]}$. On the other hand, FDI enhances the performance of the export sector through improving allocation efficiency ${ }^{[11]}$. The growth rate of FDI is much higher than other multinational enterprise activities, such as international trade ${ }^{[12]}$.

With the rapid growth of the FDI scale, the determinants of location choice have aroused considerable research interest. For the effectiveness of investment, multinational enterprises need to choose the host country according to their investment motivation. Based on the eclectic theory of international production, Dunning ${ }^{[13]}$ describes the motivation of foreign investment and divides it into four types: "Market-seeking", "Resource-seeking", "Strategic Asset-seeking" and "Efficiency-seeking". Thereafter, a series of empirical literatures were developed to explore the influencing factors of FDI. Literature on FDI identifies a variety of relevant factors, including market size, natural resource endowments, and the quality of institutions, among others ${ }^{[12]}$. However, due to the differences in sample countries and time range, the determinants obtained in relevant literature are also different ${ }^{[14]}$.

Research on the location choice of China's OFDI has also risen with the growth of China's OFDI scale. In terms of investment motivation, some researchers believe that China's OFDI belongs to "Resource-seeking" as China is in rapid economic development and has a high demand for natural resources. Other researchers argue that China's OFDI is characterized by "Market-seeking" and "Efficiency-seeking", aiming to obtain a relatively abundant and cheap labor force in the host country and transfer China's domestic excess production capacity ${ }^{[2]}$. In addition, some papers have also analyzed the restrictive factors of China's OFDI from the perspective of host countries. For example, Liu, et al. ${ }^{[15]}$ examined the impact of the informal economy on China's OFDI; Liu, et al. ${ }^{[16]}$ studied how cultural distance and its dimensions affect the spatial differences of OFDI in China; Ren and Yang ${ }^{[3]}$ analyzed the influence of the host country on China's OFDI from five dimensions, including geographical distance, economic distance, information distance, institutional distance and cultural distance.

The Belt and Road Initiative has attracted wide attention since proposed. The determinants of China's OFDI in BRI countries are also of concern, as the Chinese government strongly 
advocates investment in this area. Relevant studies have pointed out that institutional environment, market demand, economic environment and natural resources are important factors. But how their specific influence on China's OFDI is controversial. For example, Shao ${ }^{[17]}$ concluded that political risk in the host country greatly reduced China's OFDI and increased investment losses; while Yang and $\mathrm{Li}^{[1]}$ implied that government quality did not inhibit China's OFDI. The empirical results of Liu, et al. ${ }^{[18]}$ showed that China's OFDI is more inclined to invest in BRI countries with a better political environment, more abundant natural resources, higher energy efficiency, lower carbon dioxide emission intensity and less developed energy structure. Through empirical analysis, $\mathrm{Liu}^{[5]}$ found that the exchange rate level, market potential and the openness of the host country are positive determinants of China's OFDI in BRI countries, while the infrastructure is proved to be negatively correlated with China's OFDI flow.

Previous studies do not provide a systematic and up-to-date picture of host country determinants of Chinese OFDI. In this paper, we collected 27 host country-related indicators from economic environment, institutional environment, and China-related factors. Five common factors are extracted by factor analysis and a panel regression model was established to systematically examine the influencing factors of China's OFDI. Besides, we identify the difference of determination for Chinese OFDI in BRI countries and non-BRI countries.

\section{Variables and Data}

\subsection{Variables Selection}

The released data on FDI contain FDI flow and FDI stock. In this paper, the FDI flow is selected as the explained variable, specifically because the accumulated OFDI stock data varies greatly from year to year, which was unstable and could not guarantee the accuracy of regression results.

For the collection of host country-related factors, based on a systematic literature review, this paper divides the relevant factors into five dimensions: Economic environment, institutional environment, market demand, natural resource and China-related factors.

In the dimension of the economic environment, the relevant explanatory variables are as follows. Generally, the economic development of the host country, represented by GDP per capita, has a very important influence on the investment decisions of foreign enterprises. The advanced technology, which is reflected by the number of patent applications per capita, is attractive for "Strategy Asset-seeking" type FDI. High-quality labor resources may also be an important factor to attract "Efficiency-seeking" type OFDI. The enrollment rate can be used to reflect the quality of human resources in the host country, while per capita GDP can be used to replace real wages ${ }^{[5]}$. Besides, the business convenience of the host country can also directly influence FDI, representative indicators include ease of doing business, tax and infrastructure ${ }^{[19]}$. The economic and financial stability of the host country may directly be related to the success of FDI. Commonly used indicators include exchange rate stability, inflation rate, industrial structure, degree of economic freedom, economic risk, etc. ${ }^{[5,}{ }^{20]}$.

The institutional environment includes politics, laws, rules and other aspects. It is generally believed that a favorable institutional environment in the host country can provide a fair competition environment, low transaction costs and good property rights protection, while a poor 
institutional environment will bring additional transaction costs and higher operational risks ${ }^{[1]}$. The Worldwide Governance Indicators (WGI) published by World Bank measure the institutional status of major countries and regions in six dimensions: Voice and accountability, political stability, government efficiency, regulatory quality, rule of law and control of corruption ${ }^{[21,22]}$.

Market demand and its development potential are critical for "Market-seeking" type OFDI. The gross domestic product (GDP) and population are two most widely used indicators for the market demand scale, and the growth rate of GDP is used to reflect the market potential ${ }^{[23]}$.

One decisive factor of "Resource-seeking" type OFDI is the richness of the host country's natural resources, which can be represented by the ratio of total natural resources rents to $\mathrm{GDP}^{[20]}$. In addition, the resource utilization degree of the host country can also be reflected from its industrial structure. In this paper, the ratio of industrial added value to GDP is adopted.

As for the factors related to China, they can be summarized as economic distance, geographical distance and cultural distance. Among them, economic distance can reflect the trade relationship between the host country and China, which can be generally reflected by the bilateral trade volume. The geographic distance can reflect the transaction and information costs between China and the host country ${ }^{[3]}$; Cultural distance reflects the cultural differences between China and the host country ${ }^{[16]}$, and the cultural distance between the two countries is calculated based on Hofstede's index of four cultural dimensions ${ }^{[21,24]}$.

China's OFDI flow is obtained from Statics Bulletin of China's Outward Foreign Direct Investment. And the data source of 27 host countries' related indicators includes the World Bank, International Country Risk Guide (ICRG), WGI, China Statistical Yearbook, UNCTAD database, geobytes.com and geerthofstede.com. The details are shown in Table 1.

Table 1 Representative literature on the influencing factors of FDI

\begin{tabular}{|c|c|c|c|c|}
\hline Dimensions & Indicator & Symbol & Source & References \\
\hline \multirow{12}{*}{$\begin{array}{l}\text { Economic } \\
\text { environ- } \\
\text { ment }\end{array}$} & GDP growth (annual \%) & $\mathrm{X} 2$ & Word Bank & {$[20,25]$} \\
\hline & Fixed broadband subscriptions (per 100 people) & $\mathrm{X} 2$ & Word Bank & {$[5,6,20,21]$} \\
\hline & Patent applications, residents & $\mathrm{X} 6$ & Word Bank & {$[5,7]$} \\
\hline & GDP per capita (current US\$) & $\mathrm{X} 7$ & Word Bank & {$[20,25]$} \\
\hline & Ease of doing business & $\mathrm{X} 8$ & Word Bank & {$[19]$} \\
\hline & Tax revenue ( $\%$ of GDP) & $\mathrm{X} 9$ & Word Bank & {$[25]$} \\
\hline & School enrollment, tertiary (\% gross) & $\mathrm{X} 10$ & Word Bank & {$[21,26]$} \\
\hline & Exchange Rate Stability & $\mathrm{X} 11$ & ICRG & {$[5]$} \\
\hline & Real interest rate $(\%)$ & $\mathrm{X} 12$ & Word Bank & {$[19]$} \\
\hline & Annual Inflation Rate & $\mathrm{X} 13$ & ICRG & {$[20]$} \\
\hline & Economic freedom & $\mathrm{X} 15$ & EFI & {$[21]$} \\
\hline & Economic Risk & $\mathrm{X} 16$ & ICRG & {$[27]$} \\
\hline
\end{tabular}


Table 1 (continued) Representative literature on the influencing factors of FDI

\begin{tabular}{|c|c|c|c|c|}
\hline Dimensions & Indicator & Symbol & Source & References \\
\hline \multirow{7}{*}{$\begin{array}{l}\text { Institutional } \\
\text { environ- } \\
\text { ment }\end{array}$} & Voice and Accountability & $\mathrm{X} 17$ & WGI & {$[21,22]$} \\
\hline & Political Stability & $\mathrm{X} 18$ & WGI & {$[21,22]$} \\
\hline & Government Effectiveness & $\mathrm{X} 19$ & WGI & {$[21,22]$} \\
\hline & Regulatory Quality & $\mathrm{X} 20$ & WGI & {$[21,22]$} \\
\hline & Rule of Law & $\mathrm{X} 21$ & WGI & {$[21,22]$} \\
\hline & Control of Corruption & $\mathrm{X} 22$ & WGI & {$[21,22]$} \\
\hline & Political risk & $\mathrm{X} 23$ & ICRG & {$[25]$} \\
\hline \multirow{2}{*}{$\begin{array}{l}\text { Natural } \\
\text { Resources }\end{array}$} & $\begin{array}{l}\text { Total natural resources } \\
\text { rents ( } \% \text { of GDP) }\end{array}$ & $\mathrm{X} 4$ & Word Bank & {$[5,20,21]$} \\
\hline & $\begin{array}{l}\text { Industry (including } \\
\text { construction), value } \\
\text { added ( } \% \text { of GDP) }\end{array}$ & $\mathrm{X} 14$ & Word Bank & {$[5,21]$} \\
\hline \multirow{2}{*}{$\begin{array}{l}\text { Market } \\
\text { demand }\end{array}$} & GDP (current US\$) & $\mathrm{X} 2$ & Word Bank & {$[5,6,21,22,26,28]$} \\
\hline & Population, total & $\mathrm{X} 3$ & Word Bank & {$[6,21,25]$} \\
\hline \multirow{4}{*}{$\begin{array}{l}\text { China's } \\
\text { related } \\
\text { factor }\end{array}$} & $\begin{array}{l}\text { Total bilateral imports } \\
\text { and exports }\end{array}$ & $\mathrm{X} 24$ & China Statistical Yearbook & {$[28]$} \\
\hline & $\begin{array}{l}\text { Trade and Investment } \\
\text { Protection Agreement }\end{array}$ & $\mathrm{X} 25$ & UNCTAD & {$[22]$} \\
\hline & Geographical distance & $\mathrm{X} 26$ & geobytes.com & {$[22,25]$} \\
\hline & Cultural distance & $\mathrm{X} 27$ & Geerthofstede & {$[21]$} \\
\hline
\end{tabular}

\subsection{Sample Countries}

A large number of sample countries are crucial for the robustness of the empirical results. In this paper, the full sample consists of 92 countries. With the implementation of the Belt and Road Initiative, more and more countries have signed strategic cooperation agreements with China. To keep the classification of sample countries consistent, this paper, by referencing the Belt and Road Portal, divides the sample countries into 36 BRI countries and 56 non-BRI countries. The data cover the period of 2003 2019, and Table 2 lists all the sample countries.

Table 2 Sample countries list

\begin{tabular}{ll}
\hline \multicolumn{1}{c}{ BRI countries } & \multicolumn{1}{c}{ Non-BRI countries } \\
\hline United Arab Emirates, Azerbaijan, Egypt, & Algeria, Argentina, Ethiopia, Ireland, Austria, \\
Estonia, Pakistan, Belarus, Bulgaria, Poland, & Australia, Panama, Brazil, Belgium, Denmark, \\
Russia, Philippines, Czech Republic, Kuwait, & Germany, Ecuador, France, Finland, Colombia, \\
Croatia, Latvia, Lebanon, Lithuania, & Korea, Netherlands, Canada, Ghana, Zimbabwe, \\
Romania, Malaysia, Bangladesh, Serbia, & Kenya, Libya, Malta, Mali, United States, Peru, \\
Saudi Arabia, Sri Lanka, Slovakia, Slovenia, & Morocco, Mexico, South Africa, Nigeria, Norway, \\
Thailand, Turkey, Ukraine, Singapore, & Portugal, Japan, Sweden, Switzerland, Cyprus, \\
Hungary, Armenia, Iran, Israel, India, & Suriname, Tanzania, Trinidad and Tobago, Venezuela, \\
Indonesia, Jordan, Vietnam & Uganda, Uruguay, Spain, Greece, New Zealand, \\
& Jamaica, Italy, United Kingdom, Zambia, Chile \\
\hline
\end{tabular}




\subsection{Descriptive Statistics}

The statistics of the empirical variables are summarized in Table 3. Wherein, the second column shows the units of each variable. Descriptive statistics include mean value, standard deviation, variance, kurtosis, skewness, minimum value and maximum value. In addition, the number of observations of time-invariant variables is 91 , and the number of observations of other variables is 1472 .

Table 3 Descriptive statistics of variables

\begin{tabular}{cccccccccc}
\hline Variables & Units & Mean & Std. & \multicolumn{2}{c}{ Variance } & Kurtosis & Skewness & Min & Max \\
\hline Y & Ten thousand dollars & 2.564 & 10.135 & 102.723 & 99.501 & 6.406 & -114.532169 .808 \\
X1 & Billion dollars & 6.342 & 18.640 & 347.462 & 62.964 & 7.359 & 0.006 & 214.332 \\
X2 & $\%$ & 3.502 & 5.488 & 30.117 & 168.910 & 5.783 & -62.076 & 123.140 \\
X3 & Million dollars & 52.844 & 138.188 & 19095.81160 .919 & 7.353 & 0.072 & 1366.418 \\
X4 & $\%$ & 6.378 & 10.495 & 110.145 & 8.769 & 2.751 & 0.000 & 68.778 \\
X5 & $/$ & 14.263 & 13.083 & 171.172 & -0.989 & 0.554 & 0.000 & 46.901 \\
X6 & Thousand & 9.845 & 43.211 & 1867.159 & 34.243 & 5.794 & 0.000 & 368.416 \\
X7 & Ten thousand dollars & 1.961 & 2.163 & 4.680 & 2.546 & 1.572 & 0.014 & 11.882 \\
X8 & $/$ & 78.663 & 14.377 & 206.712 & 1.550 & -1.220 & 20.820 & 99.980 \\
X9 & $\%$ & 17.482 & 6.877 & 47.295 & 4.214 & 0.851 & 0.043 & 62.859 \\
X10 & $\%$ & 48.181 & 26.531 & 703.917 & -0.570 & 0.151 & 1.254 & 142.852 \\
X11 & $/$ & 9.283 & 1.338 & 1.789 & 15.784 & -3.569 & 0.000 & 10.000 \\
X12 & $\%$ & 7.043 & 39.087 & 1527.779 & 563.422 & 21.651 & -31.923 & 1158.026 \\
X13 & $\%$ & 8.638 & 1.478 & 2.184 & 7.701 & -2.206 & 0.000 & 10.000 \\
X14 & $\%$ & 28.579 & 11.189 & 125.197 & 5.252 & 1.920 & 9.368 & 87.797 \\
X15 & $/$ & 63.476 & 10.625 & 112.890 & 2.170 & -0.679 & 0.000 & 89.400 \\
X16 & $/$ & 36.516 & 5.413 & 29.296 & 4.085 & -0.911 & 0.000 & 48.500 \\
X17 & $/$ & 0.288 & 0.942 & 0.887 & -0.903 & -0.388 & -1.983 & 1.801 \\
X18 & $/$ & 0.007 & 0.944 & 0.892 & -0.571 & -0.500 & -2.810 & 1.656 \\
X19 & $/$ & 0.407 & 0.941 & 0.886 & -1.019 & 0.174 & -1.922 & 2.437 \\
X20 & $/$ & 0.396 & 0.956 & 0.914 & -0.592 & -0.256 & -2.364 & 2.261 \\
X21 & $/$ & 0.314 & 1.001 & 1.001 & -1.028 & 0.143 & -2.322 & 2.100 \\
X22 & $/$ & 0.281 & 1.052 & 1.107 & -0.950 & 0.493 & -1.627 & 2.470 \\
X23 & $/$ & 66.959 & 11.376 & 129.420 & 0.672 & -0.370 & 0.000 & 89.667 \\
X24 & $/$ & 26.859 & 62.738 & 3936.077 & 33.870 & 5.192 & 0.014 & 633.519 \\
X25 & 1.669 & 0.693 & 0.480 & 1.471 & -1.788 & 0.000 & 2.000 \\
X26 & / & 8.764 & 3.827 & 14.649 & 0.438 & 0.772 & 0.956 & 19.262 \\
X27 & 61.557 & 31.050 & 964.097 & -0.445 & 0.320 & 2.015 & 137.072 \\
\hline & & & & & & &
\end{tabular}


Figure 1 displays the correlation between explanatory variables in the form of a heat map, in which the Pearson correlation value is denoted by the value in the grid where two variables interconnect, and the grid in blue indicates a negative correlation between the two variables, while the grid in yellow indicates a positive correlation. The darker the color is, the stronger the correlation is. There is a strong correlation between some indicators.

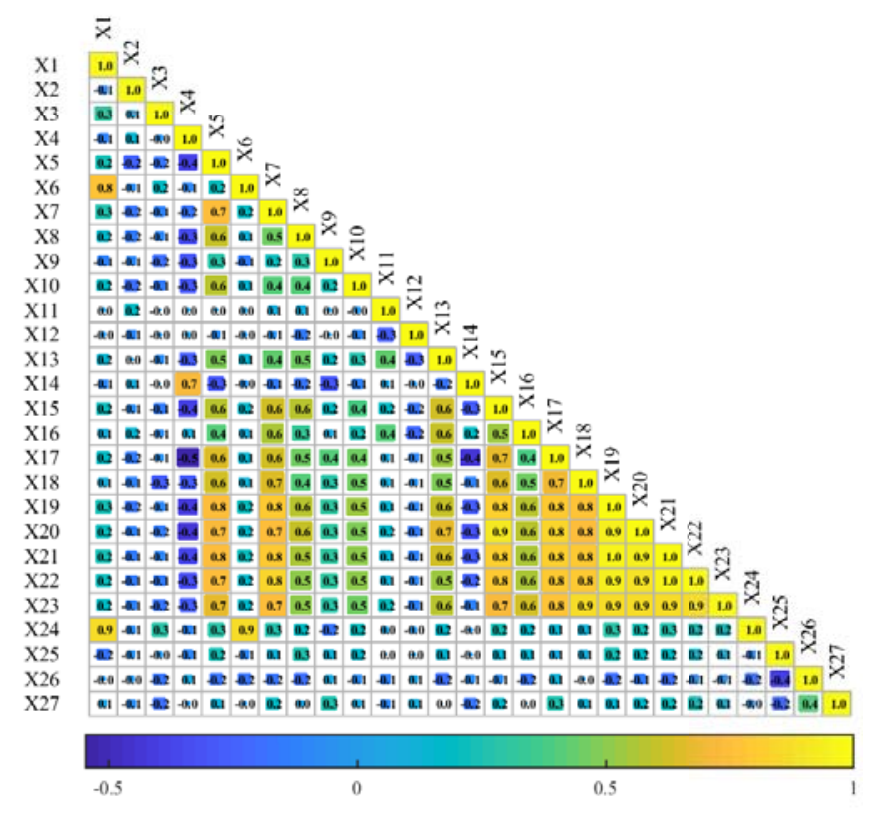

Figure 1 Correlation between explanatory variables

\section{Study Design}

\subsection{Factor Analysis}

In view that the high collinearity among explanatory variables may lead to incorrect results in the regression analysis, this paper first adopted the factor analysis method to extract the common factors among the 27 indicators. Bartlett Test of Sphericity and Kaiser-Meyer-Olkin were used to test the suitability for factor analysis. The calculated result of KMO for 27 variables was 0.897 , close to 1 , indicating that these variables were suitable for factor analysis. And the

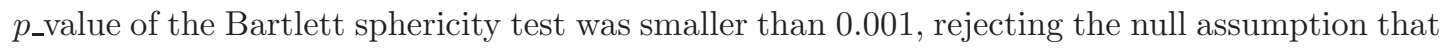
the correlation matrix is the identity matrix. For the implementation of factor analysis, the principal component method was used to calculate the factor load, and the number of common factors was determined to be 5 based on the Kaiser criterion (Eigenvalue $\geq 1$ ).

In addition, to ensure that the obtained factors have clear economic meanings, this paper uses the maximum equilibrium rotation method for factor rotation. The results show that a load of all the 27 indicators on a rotation factor is greater than 0.4 , which also demonstrates the validity of the factor analysis results.

The selected five common factors accounted for $69.4 \%$ of the total data variance. And the extracted five common factors covered the main dimensions summarized through literature 
research, which indicated that it was justified to use them in subsequent regression analysis. Table 4 displays the economic meaning of five factors and loaded variables. Among them, the variables highly related with the first factor include the rule of law, government efficiency and corruption control of the host country, which reflects the institutional environment of the host country. The host country's economic scale, technological development, and bilateral trade with China are highly loaded on the second factor, which represents the host country's market demand for foreign investment. The third factor is highly connected to natural resources and industrial structure, which reflects the utilization of natural resources in the host country. The fourth factor includes exchange rate stability, economic development, inflation, interest rate and other variables, reflecting the economic environment of the host country; The fifth factor is associated with China and corresponds to factors specific to the Chinese situation. Among them, F1 F4 is a positive factor, and the higher value denotes the better institutional environment, the stronger market demand, the higher utilization level of natural resources and the better economic environment. While F5 is a negative factor, the smaller the value is, the closer the connection with China is.

Table 4 The meaning of factors

\begin{tabular}{|c|c|c|}
\hline Factor & Meaning & Loaded factors \\
\hline $\mathrm{F} 1$ & Institutional factors & $\begin{array}{l}\text { Rule of Law, Government Efficiency, Control of } \\
\text { Corruption, Regulatory Quality, political risk, labor } \\
\text { costs, political stability, economic freedom, } \\
\text { infrastructure, voice and accountability, economic risk, } \\
\text { inflation, ease of doing business, human resources }\end{array}$ \\
\hline $\mathrm{F} 2$ & Market demand & $\begin{array}{l}\text { GDP, Fixed broadband subscriptions (per } 100 \text { people), } \\
\text { Total bilateral imports and exports, population }\end{array}$ \\
\hline F3 & Natural resources & $\begin{array}{l}\text { Total natural resource rents ( } \% \text { of GDP), Industry } \\
\text { (including construction), value added ( } \% \text { of GDP) }\end{array}$ \\
\hline $\mathrm{F} 4$ & $\begin{array}{l}\text { Economic } \\
\text { environment }\end{array}$ & $\begin{array}{l}\text { Total natural resource rents ( } \% \text { of GDP), Exchange } \\
\text { Rate Stability, GDP growth (annual \%), Annual } \\
\text { Inflation Rate, Real interest rate (\%) }\end{array}$ \\
\hline F5 & China-related factor & $\begin{array}{l}\text { Trade and Investment Protection Agreement, } \\
\text { Geographical distance, Cultural distance }\end{array}$ \\
\hline
\end{tabular}

\subsection{Panel Data Regression}

This paper performs the panel data regression analysis to test the effects of factors on China's FDI.

$$
\mathrm{FDI}_{i t}=\beta_{0}+\beta_{1} \mathrm{~F} 1_{i t}+\beta_{2} \mathrm{~F} 2_{i t}+\beta_{3} \mathrm{~F} 3_{i t}+\beta_{4} \mathrm{~F} 4_{i t}+\beta_{5} \mathrm{~F} 5_{i t}+\varepsilon_{i t},
$$

where, the $\mathrm{FDI}_{i t}$, which is the explained variable of panel regression, indicates the direct investment from China to host country $i$ at year $t . \mathrm{F} 1 \sim \mathrm{F} 5$ are five common factors obtained from factor analysis, which are the explanatory variables of the panel regression model. $\beta_{0}$ is the intercept term of regression analysis, and $\beta_{1} \sim \beta_{5}$ are the regression coefficients of factors. The overall error term $\varepsilon_{i t}$ includes random or fixed country and time effects. Before the 
model estimation process, the unit root test is conducted using the Levin, Lin and Chu (LLC) test $^{[29]}$, Fisher-PP test and Fisher-ADF test ${ }^{[30]}$. As shown in Table 5, though the variables show mixed results, at least two tests of three reject the null hypothesis at a high significance level, indicating that these three variables may be treated as stationary.

Table 5 Results of stationary tests

\begin{tabular}{llllllll}
\hline Sample & & FDI & F1 & F2 & F3 & F4 & F5 \\
\hline \multirow{3}{*}{ Full sample } & LLC & $\bullet$ & $\checkmark$ & $\checkmark$ & $\checkmark$ & $\checkmark$ & $\checkmark$ \\
& Fisher-PP & $\checkmark$ & $\checkmark$ & $\bullet$ & $\bullet$ & $\checkmark$ & $\checkmark$ \\
& Fisher-ADF & $\checkmark$ & $\checkmark$ & $\checkmark$ & $\checkmark$ & $\checkmark$ & $\checkmark$ \\
\hline \multirow{3}{*}{ BRI countries } & LLC & $\bullet$ & $\checkmark$ & $\checkmark$ & $\checkmark$ & $\checkmark$ & $\checkmark$ \\
& Fisher-PP & $\checkmark$ & $\checkmark$ & $\bullet$ & $\bullet$ & $\checkmark$ & $\checkmark$ \\
& Fisher-ADF & $\checkmark$ & $\checkmark$ & $\checkmark$ & $\checkmark$ & $\checkmark$ & $\checkmark$ \\
\hline \multirow{2}{*}{ Non-BRI countries } & LLC & $\bullet$ & $\checkmark$ & $\checkmark$ & $\checkmark$ & $\checkmark$ & $\checkmark$ \\
& Fisher-PP & $\checkmark$ & $\bullet$ & $\bullet$ & $\bullet$ & $\checkmark$ & $\checkmark$ \\
& Fisher-ADF & $\checkmark$ & $\checkmark$ & $\checkmark$ & $\checkmark$ & $\checkmark$ & $\checkmark$ \\
\hline
\end{tabular}

Note: $\checkmark$ means reject the null hypothesis at a $99 \%$ confidence level, and $\bullet$ means cannot reject the null hypothesis at a $99 \%$ confidence level.

To test for possible serial correlation, we employ the Wooldridge ${ }^{[31]}$ test. The test results for the full sample, BRI countries and non-BRI countries are $F(1,91)=0.579\left(p_{\text {-value }}=0.449\right)$, $F(1,35)=3.777\left(p_{\text {_value }}=0.060\right)$ and $F(1,55)=0.343\left(p_{\text {-value }}=0.5603\right)$. The results indicate that there is a serial correlation among variables. Moreover, the White ${ }^{[32]}$ and Breusch and Pagan ${ }^{[33]}$ test indicate a significant presence of heteroscedasticity. Therefore, this paper reports the results of robust estimates that consider sequence heteroscedasticity and autocorrelation. Besides, the results of the Hausman test for fixed or random effects rejected the null hypothesis for all models.

\subsection{Quantile Panel Regression}

The effects of factors may vary with the scale of China's OFDI. Therefore, the quantile panel regression method is adopted to estimate the regression coefficients for different quantiles of China's OFDI. The setting of quantile panel regression is as follows.

$$
Q_{\mathrm{FDI}_{i t}}\left(\tau \mid \mathrm{F}_{i t}\right)=\beta_{0}(\tau)+\beta_{1}(\tau) \mathrm{F} 1_{i t}+\beta_{2}(\tau) \mathrm{F} 2_{i t}+\beta_{3}(\tau) \mathrm{F} 3_{i t}+\beta_{4}(\tau) \mathrm{F} 4_{i t}+\beta_{5}(\tau) \mathrm{F} 5_{i t}+\varepsilon_{i t},
$$

where, $\tau \in(0,1)$ indicates the quantile, $\beta(\tau)$ is the regression which varies with $\tau$. With a reasonable quantile setting, the influencing factors of China's OFDI at different quantile levels can be explored to obtain more comprehensive results. In this paper, three quantiles are set, $\tau=0.25$ (lower quantile), $\tau=0.5$ (middle quantile) and $\tau=0.75$ (upper quantile), which correspond to the small scale, middle scale and large scale of China's OFDI. 


\section{$5 \quad$ Empirical Results}

\subsection{Basic Results of Panel Data Regression}

Table 6 reports the regression results of the panel data regression model with fixed year and time effects, in which Model (1) is the estimation result based on all sample countries, Model (2) is the result of BRI countries, and Model (3) is the estimation result for non-BRI samples.

Table 6 Estimation results of fixed effect

\begin{tabular}{|c|c|c|c|}
\hline & (1) & $(2)$ & (3) \\
\hline & Full sample & BRI countries & Non-BRI countries \\
\hline & FDI & FDI & FDI \\
\hline \multirow[t]{2}{*}{ F1 } & $0.590 * * *$ & $0.801^{* *}$ & $0.562^{* * *}$ \\
\hline & $(3.25)$ & $(1.92)$ & $(2.98)$ \\
\hline \multirow[t]{2}{*}{ F2 } & $1.728^{* * *}$ & $1.706^{* *}$ & $1.772^{* * *}$ \\
\hline & $(5.23)$ & $(3.25)$ & $(4.99)$ \\
\hline \multirow[t]{2}{*}{ F3 } & $-0.069 * * *$ & $-0.171^{* *}$ & $-0.026^{* * *}$ \\
\hline & $(-1.16)$ & $(-2.21)$ & $(-0.30)$ \\
\hline \multirow[t]{2}{*}{$\mathrm{F} 4$} & $0.022^{* * *}$ & $-0.073^{* *}$ & $0.037 * * *$ \\
\hline & $(0.96)$ & $(-1.05)$ & $(1.40)$ \\
\hline \multirow[t]{2}{*}{ F5 } & 0.047 & 0.656 & -0.089 \\
\hline & $(0.37)$ & $(1.65)$ & $(-0.67)$ \\
\hline \multirow[t]{2}{*}{ _cons } & $1.74 \times 10^{-9 * * *}$ & 0.887 & -0.112 \\
\hline & $(23.04)$ & $(1.80)$ & $(-1.11)$ \\
\hline$N$ & 1472 & 576 & 896 \\
\hline$R$-within & 0.174 & 0.150 & 0.186 \\
\hline$F$-statistics & $6.77^{* * *}$ & $6.74^{* * *}$ & $6.28 * * *$ \\
\hline
\end{tabular}

Robust standard errors in parentheses, ${ }^{* * *} p<0.01,{ }^{* *} p<0.05,{ }^{*} p<0.1$.

The regression for the full sample and non-BRI countries show that the coefficients of the institutional environment (F1) and market demand (F2) are significantly positive, indicating that favorable institutional environment and strong market demand of the host country attract China's OFDI. In agreement, Shao ${ }^{[17]}$ indicated that China's OFDI tended to countries or regions with good institutional conditions and large market scale. The main reasons are as follows. On the one hand, the stable regime, reasonable supervision and perfect legal system in the host country provide a foreign investment with long-term and stable development prospects and predictable benefits. On the other hand, Chinese enterprises with overseas investment have been shouldering the major task of cutting overcapacity. The great market demand can combine China's competitive capacity with the actual market demand of the host country to achieve a "win-win".

As for the regression results for BRI countries, the coefficient of natural resource (F3) is significantly negative. Although some countries are rich in natural resources, the utilization 
rate is low due to technical limitations. China's OFDI can promote technological progress and infrastructure development, which are conducive to the resource development, acquisition and utilization in these countries. The empirical results of $\mathrm{Liu}^{[18]}$ also show that Chinese enterprises tend to invest in countries with the better political environment and natural resource endowment, but low carbon dioxide emission intensity and underdeveloped energy structure, technology and infrastructure.

\subsection{Heterogeneity in Time}

Since 2012, China's economy has ceased its rapid growth and entered the "new normal" period. China has begun to optimize the structure of overseas investment and make innovations in the way of outbound investment. To investigate the changes in the determinants of China's OFDI after the "new normal", this paper divides the samples into two periods before 2012 and after 2012 for comparative analysis. And the regression results are reported in Table 7.

Table 7 Estimation results of fixed effect (before 2012 and after 2012)

\begin{tabular}{|c|c|c|c|c|c|c|}
\hline & (1) & $(2)$ & (3) & (4) & $(5)$ & (6) \\
\hline & \multicolumn{2}{|c|}{ Full sample } & \multicolumn{2}{|c|}{ BRI countries } & \multicolumn{2}{|c|}{ Non-BRI countries } \\
\hline & Before 2012 & After 2012 & Before 2012 & After 2012 & Before 2012 & After 2012 \\
\hline & FDI & FDI & FDI & FDI & FDI & FDI \\
\hline \multirow[t]{2}{*}{ F1 } & $0.238^{*}$ & $0.394^{*}$ & 0.212 & 0.639 & 0.373 & 0.360 \\
\hline & $(1.73)$ & $(1.71)$ & $(1.28)$ & $(1.59)$ & $(1.34)$ & (1.19) \\
\hline $\mathrm{F} 2$ & $0.719^{* * *}$ & 0.222 & $1.081^{* * *}$ & 0.570 & $0.663^{* * *}$ & 0.196 \\
\hline$(3.75)$ & $(0.75)$ & $(2.81)$ & $(1.55)$ & $(3.17)$ & $(0.48)$ & \\
\hline F3 & -0.0179 & -0.0598 & -0.0483 & $-0.114^{*}$ & -0.0274 & -0.0566 \\
\hline$(-0.20)$ & $(-0.87)$ & $(-1.04)$ & $(-1.76)$ & $(-0.19)$ & $(-0.42)$ & \\
\hline $\mathrm{F} 4$ & -0.00451 & 0.0660 & 0.0111 & -0.0599 & -0.00382 & 0.121 \\
\hline$(-0.23)$ & $(1.05)$ & $(0.47)$ & $(-1.37)$ & $(-0.15)$ & $(1.26)$ & \\
\hline F5 & 0.0309 & $-0.413^{* *}$ & 0.106 & -0.178 & 0.0188 & $-0.467^{* *}$ \\
\hline$(0.54)$ & $(-2.14)$ & $(0.80)$ & $(-0.38)$ & $(0.27)$ & $(-2.03)$ & \\
\hline _cons & $-0.103^{* * *}$ & $0.0676^{*}$ & 0.119 & 0.0760 & $-0.197^{* *}$ & $0.281^{*}$ \\
\hline$(-6.23)$ & $(1.90)$ & $(0.57)$ & $(0.16)$ & $(-2.66)$ & $(1.86)$ & \\
\hline$N$ & 736 & 736 & 288 & 288 & 448 & 448 \\
\hline$R$-within & 0.0853 & 0.0065 & 0.1461 & 0.0218 & 0.0795 & 0.0069 \\
\hline$F$-statistics & $3.27^{* * *}$ & $2.09^{*}$ & $3.82^{* * *}$ & 1.53 & $2.23^{*}$ & $2.03^{*}$ \\
\hline
\end{tabular}

Robust standard errors in parentheses, ${ }^{* * *} p<0.01,{ }^{* *} p<0.05,{ }^{*} p<0.1$. 
For the estimation results of the full sample and non-BRI countries, the institutional environment of the host country has always been an important factor affecting China's OFDI. In addition, before 2012, the host country's market demand (F2) had a significant impact on China's OFDI, while after 2012, China-related factor (F5) became significant, which is a reflection of China's gradually increasing international influence. Close economic and trade relations between China and host countries have promoted overseas investment.

As to BRI countries, China's OFDI was more biased toward countries with high market demand before 2012, while after 2012, China's OFDI was more inclined toward countries with low resource utilization. This may be related to the BRI initiative proposed by China in 2013. The Chinese government supports the trinity of "Aid", "Trade" and "FDI", so China's investment in BRI countries is concentrated in the infrastructure sector. Compared with most of the BRI countries, China has a technological comparative advantage, which can promote the host countries to make full use of their resources for economic advantage ${ }^{[15]}$.

\subsection{Heterogeneity in Scale}

The quantile regression can reflect the heterogeneous influence of factors on a different scale of China's OFDI. The quantile regression results for the full sample, BRI countries and non-BRI countries are reported in Table 8. The regression results of the full sample and BRI countries show that most of the factors have a significant impact on large-scale and small-scale China's OFDI while having no significant effects on medium-sized China's OFDI. The possible reason is that small OFDI generally corresponds to the initial investment of multinational enterprises in a certain host country market. Due to the lack of experience, multinational enterprises will consider various factors more carefully in location selection. The regression results show that the market demand (F2), natural resources (F3) and the China-related factors (F5) have significant effects on small-scale Chinese OFDI. On the other hand, the success of large-scale OFDI is crucial to corporate profits, thus China's large-scale OFDI location selection is cautious, and the institutional environment (F1), market demand (F2) and China's factors (F5) are the main factors to be considered.

The regression results for BRI countries show that the factors all have significant influences on China's OFDI, which indicates that Chinese enterprises will consider all factors when investing in BRI countries. It is worth pointing out that, for China's large-scale investment in BRI countries, the institutional environment (F1) has no significant influence, while the regression coefficient of market demand (F3) is higher than that of small and middle scale. The possible reason is that the overall institutional risk of BRI countries is relatively high. China's investment in BRI countries pays more attention to the market demand, which can be combined with China's superior production capacity. Besides, the empirical results of $\mathrm{Li}$, et al. ${ }^{[34]}$ indicated that although there was no direct correlation between stable politics and more China's OFDI, political stability played a moderating role in the relationship between economic development and China's OFDI. 
Table 8 Estimation results of quantile regression

\begin{tabular}{|c|c|c|c|c|c|}
\hline & F1 & $\mathrm{F} 2$ & F3 & F4 & F5 \\
\hline \multicolumn{6}{|c|}{ Full sample: } \\
\hline \multirow[t]{2}{*}{$\tau=0.25$} & 0.0134 & $0.119^{* * *}$ & $0.00313^{*}$ & 0.00283 & $-0.00588^{* * *}$ \\
\hline & $(1.51)$ & $(5.43)$ & $(1.92)$ & $(1.58)$ & $(-3.07)$ \\
\hline \multirow[t]{2}{*}{$\tau=0.5$} & -0.866 & -0.475 & 0.173 & -0.00547 & 0.478 \\
\hline & $(-0.35)$ & $(-0.27)$ & $(0.36)$ & $(-0.13)$ & $(0.34)$ \\
\hline \multirow[t]{2}{*}{$\tau=0.750$} & $0.0942^{* * *}$ & $0.506^{* * *}$ & 0.0177 & 0.00726 & $-0.0362 * * *$ \\
\hline & $(10.74)$ & $(80.05)$ & $(1.59)$ & $(1.15)$ & $(-3.62)$ \\
\hline \multicolumn{6}{|c|}{ BRI countries: } \\
\hline \multirow{2}{*}{$\tau=0.25$} & $0.00815^{* * *}$ & $0.0357^{* * *}$ & $0.00372^{* * *}$ & $0.00171^{* * *}$ & $0.00310^{* * *}$ \\
\hline & $(11.47)$ & $(15.22)$ & $(6.68)$ & $(3.24)$ & $(3.65)$ \\
\hline \multirow[t]{2}{*}{$\tau=0.5$} & $0.0358^{* * *}$ & $0.196^{* * *}$ & $-0.00691^{* * *}$ & $0.00829 * * *$ & $-0.0256^{* * *}$ \\
\hline & $(40.95)$ & $(28.93)$ & $(-2.84)$ & $(2.92)$ & $(-7.32)$ \\
\hline \multirow[t]{2}{*}{$\tau=0.75$} & 0.00993 & $0.698^{* * *}$ & $-0.0383^{* * *}$ & -0.0113 & $0.0975^{*}$ \\
\hline & $(0.21)$ & $(9.45)$ & $(-3.08)$ & $(-0.72)$ & $(1.73)$ \\
\hline \multicolumn{6}{|c|}{ Non-BRI countries: } \\
\hline \multirow[t]{2}{*}{$\tau=0.25$} & $0.00283^{*}$ & $0.0316^{* * *}$ & $0.00540^{* * *}$ & $0.00156^{* *}$ & $-0.00785^{* * *}$ \\
\hline & $(1.74)$ & $(26.76)$ & $(2.86)$ & $(2.33)$ & $(-5.07)$ \\
\hline \multirow[t]{2}{*}{$\tau=0.5$} & 0.0175 & 0.275 & 0.0244 & 0.00332 & 0.0158 \\
\hline & $(1.57)$ & $(1.31)$ & $(1.31)$ & $(1.28)$ & $(0.41)$ \\
\hline \multirow[t]{2}{*}{$\tau=0.75$} & $0.0676 * * *$ & $0.492^{* * *}$ & $0.0817^{* * *}$ & $0.0187^{* *}$ & 0.00165 \\
\hline & $(3.41)$ & (13.39) & $(2.73)$ & $(2.15)$ & $(0.06)$ \\
\hline
\end{tabular}

Robust standard errors in parentheses, ${ }^{* * *} p<0.01,{ }^{* *} p<0.05,{ }^{*} p<0.1$.

\subsection{Robustness Test}

To test the robustness of the experimental results, we take the FDI stock as the explained variable. The results of panel data regression and quantile panel regression are shown in Tables $9 \sim 11$. The estimation results of the fixed-effect model also show that the institutional environment and market demand of the host country have a significantly positive impact on China's OFDI stock. For BRI countries, the coefficient of natural resource utilization status is significantly negative, which is consistent with the results of OFDI flow. By comparing the regression results before and after 2012, it can be found that the influencing factors of China's OFDI stock have changed, and the obvious feature is that China's OFDI is more inclined to the regions with low utilization of natural resources. However, the results of quantile regression show some difference from FDI flows, possibly because OFDI stock accumulates over the years. 
Table 9 Estimation results of fixed effect (on FDI stock)

\begin{tabular}{cccc}
\hline & $(1)$ & $(2)$ & $(3)$ \\
\cline { 2 - 4 } & Full sample & BRI countries & Non-BRI countries \\
\cline { 2 - 4 } & FDI stock & FDI stock & FDI stock \\
\hline \multirow{2}{*}{ F1 } & $0.718^{* * *}$ & $1.119^{*}$ & $0.562^{* *}$ \\
& $(3.08)$ & $(2.02)$ & $(2.59)$ \\
& $2.465^{* * *}$ & $1.900^{* * *}$ & $2.593^{* * *}$ \\
F3 & $(5.13)$ & $(3.46)$ & $(5.40)$ \\
& -0.107 & $-0.330^{* * *}$ & 0.00980 \\
F4 & $(-1.20)$ & $(-2.80)$ & $(0.08)$ \\
& 0.0354 & -0.0840 & $0.0532^{* *}$ \\
F5 & $(1.43)$ & $(-1.06)$ & $(2.02)$ \\
& 0.0568 & 0.904 & -0.186 \\
_cons & $(0.27)$ & $(1.66)$ & $(-0.82)$ \\
& $8.65 \times 10^{-10 * * *}$ & $1.192^{*}$ & -0.0775 \\
$N$ & $(11.08)$ & $(1.81)$ & $(-0.51)$ \\
\hline -within & 1472 & 576 & 896 \\
$F$-statistics & 0.4199 & 0.1950 & 0.5206 \\
\hline
\end{tabular}

Robust standard errors in parentheses, ${ }^{* * *} p<0.01,{ }^{* *} p<0.05,{ }^{*} p<0.1$.

Table 10 Estimation results of fixed effect before 2012 and after 2012 (on FDI stock)

\begin{tabular}{|c|c|c|c|c|c|c|}
\hline & (1) & $(2)$ & (3) & (4) & $(5)$ & (6) \\
\hline & \multicolumn{2}{|c|}{ Full sample } & \multicolumn{2}{|c|}{ BRI countries } & \multicolumn{2}{|c|}{ Non-BRI countries } \\
\hline & Before 2012 & After 2012 & Before 2012 & After 2012 & Before 2012 & After 2012 \\
\hline & FDI stock & FDI stock & FDI stock & FDI stock & FDI stock & FDI stock \\
\hline \multirow[t]{2}{*}{$\mathrm{F} 1$} & $0.116^{*}$ & $1.150^{* *}$ & 0.143 & $1.150 * *$ & $1.179^{* *}$ & 1.012 \\
\hline & $(1.75)$ & $(2.26)$ & $(1.68)$ & $(2.26)$ & $(2.61)$ & $(1.64)$ \\
\hline \multirow[t]{2}{*}{$\mathrm{F} 2$} & $0.564^{* * *}$ & 2.558 & $0.810^{* * *}$ & 2.558 & 0.271 & $3.157^{*}$ \\
\hline & $(5.00)$ & $(1.56)$ & $(3.36)$ & $(1.56)$ & $(0.54)$ & $(1.71)$ \\
\hline \multirow[t]{2}{*}{ F3 } & -0.0327 & $-0.258^{* *}$ & -0.0503 & $-0.258^{* *}$ & $-0.286^{* * *}$ & -0.181 \\
\hline & $(-0.82)$ & $(-2.17)$ & $(-1.33)$ & $(-2.17)$ & $(-2.94)$ & $(-1.01)$ \\
\hline \multirow[t]{2}{*}{$\mathrm{F} 4$} & 0.00154 & 0.0317 & 0.00637 & 0.0317 & -0.0601 & $0.0962^{*}$ \\
\hline & $(0.34)$ & $(0.78)$ & $(0.82)$ & $(0.78)$ & $(-1.12)$ & $(1.78)$ \\
\hline \multirow[t]{2}{*}{ F5 } & 0.0137 & 0.380 & 0.0938 & 0.380 & 0.511 & 0.0698 \\
\hline & $(0.36)$ & $(0.69)$ & $(1.27)$ & $(0.69)$ & $(0.58)$ & $(0.14)$ \\
\hline \multirow[t]{2}{*}{ _cons } & $-0.206^{* * *}$ & 0.0643 & -0.0244 & 0.0643 & 0.856 & -0.282 \\
\hline & $(-28.07)$ & $(0.77)$ & $(-0.21)$ & $(0.77)$ & $(0.94)$ & $(-0.56)$ \\
\hline$N$ & 736 & 736 & 288 & 736 & 288 & 448 \\
\hline$R$-within & 0.2625 & 0.1766 & 0.2323 & 0.1766 & 0.0769 & 0.2746 \\
\hline$F$-statistics & $13.44^{* * *}$ & $2.67^{* *}$ & $7.02^{* * *}$ & $2.67^{* *}$ & $4.00^{*}$ & 1.30 \\
\hline
\end{tabular}

Robust standard errors in parentheses, ${ }^{* * *} p<0.01,{ }^{* *} p<0.05,{ }^{*} p<0.1$. 
Table 11 Estimation results of quantile regression

\begin{tabular}{|c|c|c|c|c|c|}
\hline & $\mathrm{F} 1$ & $\mathrm{~F} 2$ & F3 & $\mathrm{F} 4$ & F5 \\
\hline \multicolumn{6}{|c|}{ Full sample: } \\
\hline \multirow[t]{2}{*}{$\tau=0.25$} & -0.0778 & $0.222^{* * *}$ & $-0.00652^{* * *}$ & -0.00874 & 0.122 \\
\hline & $(-1.39)$ & $(3.84)$ & $(-2.58)$ & $(-1.01)$ & $(1.05)$ \\
\hline \multirow[t]{2}{*}{$\tau=0.5$} & 0.00578 & $0.205^{* * *}$ & $-0.0704^{*}$ & $0.0236^{*}$ & $-0.0131^{* *}$ \\
\hline & $(0.54)$ & $(6.19)$ & $(-1.91)$ & $(1.76)$ & $(-2.55)$ \\
\hline \multirow[t]{2}{*}{$\tau=0.75$} & $0.121^{* * *}$ & $0.784^{* * *}$ & 0.0294 & 0.00692 & $0.0553^{* * *}$ \\
\hline & $(7.76)$ & $(8.56)$ & $(1.18)$ & $(0.39)$ & $(2.68)$ \\
\hline \multicolumn{6}{|c|}{ BRI countries: } \\
\hline \multirow[t]{2}{*}{$\tau=0.25$} & 0.00587 & $0.0762^{* * *}$ & $-0.00345^{* * *}$ & 0.00177 & $-0.00696^{* * *}$ \\
\hline & $(1.27)$ & $(61.02)$ & $(-4.81)$ & (1.49) & $(-4.54)$ \\
\hline \multirow[t]{2}{*}{$\tau=0.5$} & -0.0116 & $0.299^{* * *}$ & 0.0181 & -0.0236 & 0.0872 \\
\hline & $(-0.18)$ & $(9.29)$ & $(0.98)$ & $(-1.13)$ & $(0.75)$ \\
\hline \multirow[t]{2}{*}{$\tau=0.75$} & $0.149 * * *$ & $1.233^{* * *}$ & -0.00512 & 0.00216 & $0.139 *$ \\
\hline & $(3.28)$ & $(4.06)$ & $(-0.24)$ & $(0.17)$ & $(1.90)$ \\
\hline \multicolumn{6}{|c|}{ Non-BRI countries: } \\
\hline \multirow[t]{2}{*}{$\tau=0.25$} & -0.00178 & $0.0517^{* *}$ & -0.0203 & 0.00302 & 0.0332 \\
\hline & $(-0.13)$ & $(2.46)$ & $(-1.49)$ & $(0.67)$ & $(1.30)$ \\
\hline \multirow[t]{2}{*}{$\tau=0.5$} & 0.0297 & 0.317 & 0.00893 & 0.00775 & -0.0241 \\
\hline & $(0.82)$ & $(0.73)$ & $(1.35)$ & $(0.75)$ & $(-0.43)$ \\
\hline \multirow[t]{2}{*}{$\tau=0.75$} & $0.519^{*}$ & $0.520 * * *$ & $0.306^{* *}$ & -0.129 & 1.724 \\
\hline & $(1.80)$ & $(2.94)$ & $(2.09)$ & $(-0.94)$ & $(1.49)$ \\
\hline
\end{tabular}

Robust standard errors in parentheses, ${ }^{* * *} p<0.01,{ }^{* *} p<0.05,{ }^{*} p<0.1$.

\section{Conclusions and Implications}

This paper explores the determinants of the location choice of China's OFDI. Based on a systematic literature review, this paper collected 27 host countries related indicators. The factor analysis method is adopted to extracted five common factors, which are institutional environment, market demand, natural resources, economic environment and China-related factors. In the empirical analysis, the panel data regression and a quantile regression model are used for the full sample, BRI counties and non-BRI countries. The conclusions are as follows.

1) The favorable institutional environment and great market demand of the host country are important factors attracting China's OFDI. Besides, China's OFDI to BRI countries tends to countries with unreasonable energy structure and less developed technology. China's OFDI contributes to the technological progress and economic development of host countries.

2) As China's economy enters "new normal" and the BRI was implemented, the determines of China's OFDI has changed. The China-related factor is gradually prominent, which is a manifestation of China's increasing international influence. The sound economic and trade 
relations between China and host countries have promoted China's OFDI.

3) The institutional environment of the host country has little influence on large-scale China's OFDI in BRI countries, while the market demand has a higher influence. This evidence indicates that China's OFDI in BRI countries is more focused on the market demand, which can combine China's superior production capacity with the actual demand of BRI countries.

In this paper, the regression analysis is conducted based on the extracted common factors. It should be pointed out that feature extraction methods including factor analysis may have the problem of information omission. One of the research prospects of this paper is to explore a feature extraction method with higher information retention. Nevertheless, the research results of this paper are important and meaningful. The conclusions obtained in this paper may provide significant implications for China's outbound investment.

For one thing, it is necessary to improve the risk prevention and security guarantee mechanism for Chinese enterprises' overseas investment. In general, the overall scale of China's OFDI has developed rapidly, but due to the complex and changeable international economic and trade environment, the cases of failure investment also rise. Chinese enterprises, especially small and medium-sized enterprises cannot make a comprehensive and detailed assessment of the investment environment of the host country, which may lead to wrong investment decisions. The empirical results show that China's OFDI pays more attention to the political environment and market demand in the process of outbound investment, while the effects of the economic environment on China's OFDI are not obvious. Therefore, there is necessary to improve the risk prevention and security ability of Chinese enterprises. Authoritative and in-depth analysis can be made on the investment environment and risks of various countries from the national level, to better guarantee the safety of Chinese enterprises' overseas investment.

For another thing, establish and further promote the BRI initiative to facilitate Chinese enterprises' investment in BRI countries. Empirical results show that the influence of Chinarelated factors on China's OFDI is gradually important. Since proposed, the BRI has played a positive role in driving Chinese enterprises' investment in BRI countries. With the rapid changes in the world, China should actively promote the cooperation with countries along the Belt and Road to well-facilitate the foreign investment of Chinese enterprises.

\section{References}

[1] Yang Y, Li X. The quality of host government and China's OFDI: Construction of micro-evaluation model of government quality. Journal of Asian Economics, 2021, 74: 101313.

[2] Kolstad I, Wiig A. What determines Chinese outward FDI? Journal of World Business, 2012, 47(1): 26-34.

[3] Ren X, Yang S. Empirical study on location choice of Chinese OFDI. China Economic Review, 2020, 61: 101428.

[4] Nugent J B, Lu J. China's outward foreign direct investment in the Belt and Road Initiative: What are the motives for Chinese firms to invest? China Economic Review, 2021, 68: 101628.

[5] Liu H Y, Tang Y K, Chen X L, et al. The determinants of Chinese outward FDI in countries along "One Belt One Road". Emerging Markets Finance and Trade, 2017, 53(6): 1374-1387.

[6] Oro O U, Alagidede I P. Does petroleum resources or market size drive foreign direct investment in Africa? New evidence from time-series analysis. Resources Policy, 2021, 71: 101992.

[7] Villaverde J, Maza A. The determinants of inward foreign direct investment: Evidence from the European regions. International Business Review, 2015, 24(2): 209-223.

[8] Arif A, An P, Qi Y, et al. The influence factors of the national roles in the FDI network: A combined methods 
of complex networks and panel data analysis. Physica A: Statistical Mechanics and Its Applications, 2021, 563: 125311.

[9] Luo S, Shi Y, Sun Y, et al. Can FDI and ODI two-way flows improve the quality of economic growth? Empirical Evidence from China. Applied Economics, 2021, 53(44): 5028-5050.

[10] Fu X, Buckley P J, Fu X M. The growth impact of Chinese direct investment on host developing countries. International Business Review, 2020, 29(2): 101658.

[11] Gupta K, Ahmed S. Determinants of FDI in South Asia: Does corruption matter? International Journal of Economics and Business Research, 2018, 16(2): 137-161.

[12] Blonigen B A. A review of the empirical literature on FDI determinants. Atlantic Economic Journal, 2005, 33(4): 383-403.

[13] Dunning J H. Location and the multinational enterprise: A neglected factor? Journal of International Business Studies, 1998, 29(1): 45-66.

[14] Han B J, Xue Q Z. The effect pf the corruption of the host countries on the FRI and its sources. Contemporary Finance \& Economics, 2008, 2: 99-105.

[15] Liu A, Wang Z, Zhu P. Does informal economy undermine the effects of China's aid on its outward foreign direct investment? International Review of Economics \& Finance, 2021, 75: 315-329.

[16] Liu Y, Ge Y, Hu Z, et al. Culture and capital flows-Exploring the spatial differentiation of China's OFDI. China Economic Review, 2018, 48: 27-45.

[17] Shao X. Chinese OFDI responses to the BRI initiative: Evidence from a quasi-natural experiment. China Economic Review, 2020, 61: 101435.

[18] Liu H, Wang Y, Jiang J, et al. How green is the "Belt and Road Initiative"? — Evidence from Chinese OFDI in the energy sector. Energy Policy, 2020, 145: 111709.

[19] Contractor F J, Dangol R, Nuruzzaman N, et al. How do country regulations and business environment impact foreign direct investment (FDI) inflows? International Business Review, 2020, 29(2): 101640.

[20] Cleeve E A, Debrah Y, Yiheyis Z. Human capital and FDI inflow: An assessment of the African case. World Development, 2015, 74: 1-14.

[21] Lucke N, Eichler S. Foreign direct investment: The role of institutional and cultural determinants. Applied Economics, 2016, 48(11): 935-956.

[22] Cezar R, Escobar O R. Institutional distance and foreign direct investment. Review of World Economics, 2015, 151(4): 713-733.

[23] Belgibayeva A, Plekhanov A. Does corruption matter for sources of foreign direct investment? Review of World Economics, 2019, 155(3): 487-510.

[24] Hofstede G. Cultures and organizations: Software of the mind. New York: Mcgraw-hill, 2014.

[25] Demir F, Hu C. Institutional differences and the direction of bilateral foreign direct investment flows: Are south-south flows any different than the rest? The World Economy, 2016, 39(12): 2000-2024.

[26] Nguyen A T N, Haug A A, Owen P D, et al. What drives bilateral foreign direct investment among Asian economies? Economic Modelling, 2020, 93: 125-141.

[27] Kellard N M, Kontonikas A, Lamla M J, et al. Risk, financial stability and FDI. Journal of International Money and Finance, 2022, 120: 102232.

[28] Azam M, Haseeb M. Determinants of foreign direct investment in BRICS - Does renewable and nonrenewable energy matter? Energy Strategy Reviews, 2021, 35: 100638.

[29] Levin A, Lin C F, Chu C S J. Unit root tests in panel data: Asymptotic and finite-sample properties. Journal of Econometrics, 2002, 108(1): 1-24.

[30] Maddala G S, Wu S. A comparative study of unit root tests with panel data and new simple test. Oxford Bulletin of Economics \& Statistics, 1999, 61(S1): 631-652.

[31] Wooldridge J M. Econometric analysis of cross section and panel data. Mit Press, 2010.

[32] White H. A heteroskedasticity-consistent covariance matrix estimator and a direct test for heteroskedasticity. Econometrica, 1980, 48(4): 817-838.

[33] Breusch T S, Pagan A R. A simple test for heteroscedasticity and random coefficient variation. Econometrica, 1979, 47(5): 1287-1294.

[34] Li H, Xiao H, Gong T. The impact of economic well-being on perceptions of anti-corruption performance: Evidence from China. Policy and Society, 2017, 34(2): 97-109. 